\title{
Characterization, Functional Properties, and Resistant Starch of Freshwater Macrophytes
}

\author{
Farahin N. N. Syed $\mathbb{D}^{1},{ }^{1}$ Muta H. Zakaria $\mathbb{D}^{1,2}$ Japar S. Bujang $\mathbb{D}^{3}{ }^{3}$ and Annie Christianus $\mathbb{D}^{1}$ \\ ${ }^{1}$ Department of Aquaculture, Faculty of Agriculture, Universiti Putra Malaysia, 43400 UPM Serdang, \\ Selangor Darul Ehsan, Malaysia \\ ${ }^{2}$ International Institute of Aquaculture and Aquatic Sciences (i-AQUAS), Universiti Putra Malaysia, 71050 Port Dickson, \\ Negeri Sembilan, Malaysia \\ ${ }^{3}$ Department of Biology, Faculty of Science, Universiti Putra Malaysia, 43400 UPM Serdang, Selangor Darul Ehsan, Malaysia
}

Correspondence should be addressed to Muta H. Zakaria; muta@upm.edu.my

Received 20 April 2020; Revised 12 December 2020; Accepted 30 December 2020; Published 21 January 2021

Academic Editor: Ivan Salmeron

Copyright (c) 2021 Farahin N. N. Syed et al. This is an open access article distributed under the Creative Commons Attribution License, which permits unrestricted use, distribution, and reproduction in any medium, provided the original work is properly cited.

\begin{abstract}
Several aquatic macrophytes such as Colocasia esculenta, Eleocharis dulcis, Nelumbo nucifera, Sagittaria sagittifolia, Trapa bispinosa, and Typha angustifolia possessed carbohydrate mainly in their storage and reproductive parts. Starch morphology, total starch, and amylose content of these six freshwater plant species were determined. Their functional properties, i.e., starch crystallinity, thermal properties, and rheological behaviour were assessed. Large starch granules were in N. nucifera rhizome $(>15 \mu \mathrm{m})$, medium-sized was $N$. nucifera seed $(8-18 \mu \mathrm{m})$, while the rest of the starches were small starch granules $(<8 \mu \mathrm{m})$. Shapes of the starch granules varied from oval and irregular with centric hilum to elongated granules with the eccentric hilum. Eleocharis dulcis corm starch had significantly higher total starch content (90.87\%), followed by corms of C. esculenta (82.35\%) and S. sagittifolia (71.71\%). Nelumbo nucifera seed starch had significantly higher amylose content (71.45\%), followed by $T$. angustifolia pollen (36.47\%). In comparison, the waxy starch was in N. nucifera rhizome (7.63\%), T. bispinosa seed (8.83\%), C. esculenta corm (10.61\%), and T. angustifolia rhizome (13.51\%). Higher resistant starch was observed mostly in rhizomes of $N$. nucifera $(39.34 \%)>$ T. angustifolia $(37.19 \%)$ and corm parts of E. dulcis $(37.41 \%)>$ S. sagittifolia (35.09\%) compared to seed and pollen starches. The XRD profiles of macrophytes starches displayed in all the corms and $N$. nucifera seed had A-type crystallinity. The $T$. bispinosa seed had $\mathrm{C}_{\mathrm{A}}$-type, whereas the rest of the starches exhibited $\mathrm{C}_{\mathrm{B}}$-type crystallinity. Waxy starches of C. esculenta corm had higher relative crystallinity (36.91\%) and viscosity ( $46.2 \mathrm{mPa}$ ) than regular starches. Based on thermal properties, high-amylose of $N$. nucifera seed and T. angustifolia pollen resulted in higher gelatinization enthalpy (19.93 and $18.66 \mathrm{Jg}^{-1}$, respectively). Starch properties showed equally good potential as commercial starches in starch-based food production based on their starch properties and functionality.
\end{abstract}

\section{Introduction}

Starch plays a vital role in food and nonfood industries, e.g., pharmaceutical, paper, textiles, biomedical, and polymer, because of its gelling characteristics, thickening, water binder, and food system stabilizing capacities [1]. Research on the structure and physicochemical properties of starch in cultivated plants, Zea mays (maize), Manihot esculenta (cassava), and Solanum tuberosum (potato) resulted in their extensive utilization in food industries. However, other plants besides those mentioned above may possess potential and promising alternative starch sources.

Over the years, aquatic plants' usage has become increasingly important; for example, rice, Oryza sativa, is a human staple diet [2]. Detailed studies of starch isolated from aquatic macrophytes are increasing and mostly focused on specific plants such as water chestnut, lotus, rice, and taro. Asian countries such as China and Japan had cultivated aquatic macrophytes such as lotus (Nelumbo nucifera), Chinese water chestnut (Eleocharis dulcis), water caltrop (Trapa 
bispinosa), taro (Colocasia esculenta), and arrowhead (Sagittaria sp.) for starch-based food. The research conducted showed that starches from macrophytes could also be a promising candidate as an energy source in the food-related industry. Water chestnut corm flour as a thickening agent and dusting powder in food preparation [3], arrowhead corms, and water caltrop fruits are eaten boiled or cooked and can be dried and ground into a powder $[4,5]$. Taro tuber possesses low fat, high carbohydrate, and minerals content and suitable as a food ingredient for baby food, chips, and bread [6]. Lotus seeds, consumed boiled or processed into powder, are also used in the pharmaceutical industry to treat inflammation, arrhythmia, cancer, and skin diseases [7]. Most of the starch's diverse uses are from cultivated species [8-11], and research on the wild species is still scarce [12].

Research on starch isolated from freshwater macrophytes such as cattails, arrowhead, yellow nutsedge, and duckweed and their physicochemical properties are also available and less prevalent $[13,14]$. Although consumed by local communities, their local utilization was seldom reported in the literature. Nowadays, consumers are engaging with resistant starch (RS) to promote health benefits similar to highamylose starch. RS is poorly digested starches and absorbed in healthy individuals' small intestine due to its complex molecular structure [15]. They are either entirely or partially fermented as a food source for bacteria, primarily inhabiting the colon. There are limited studies conducted regarding RS in aquatic macrophytes starches.

Investigating the aquatic macrophytes starches, among others, is to create awareness of their various uses and economic values. For those involved in aquatic macrophytes, it can be part of their added income generation. This study also investigated the potential use of aquatic macrophytes starches in other applications in a starch-based industry. Thus, the present study was to systematically evaluate the starch structure, composition, functional properties, and also their resistant starch (RS) content isolated from selected commonly consumed aquatic macrophytes such as taro, lotus, and water chestnut and rarely consumed, e.g., arrowhead, water caltrop, and cattail in Malaysia.

\section{Materials and Methods}

2.1. Plant Materials. Two kilograms (2) kg of edible storage organ from five macrophytes species; corms of E. dulcis, S. sagittifolia, and C. esculenta; rhizomes of N. nucifera and T. angustifolia; seeds of $N$. nucifera and T. bispinosa; and pollen of $T$. angustifolia were peeled, washed, and isolated for starches.

2.2. Isolation of Native Starch. Native starch was isolated following a method described by Vasanthan [16] with a slight modification. The plant materials were added to water in a ratio of $1: 10$. The mixture was then blended for 5-10 minutes until a smooth slurry is formed. Approximately $0.01 \%(w / v)$ sodium metabisulfite was added into the slurry and left for 30 minutes before filtering using $100 \mu \mathrm{m}$ nylon mesh cloth. The filtrated starch was centrifuged at $8000 \mathrm{rpm}$ at $20^{\circ} \mathrm{C}$ for 20 minutes. The supernatant was discarded, and the pellet was oven-dried at $40^{\circ} \mathrm{C}$ for 24 hours. The dried starch was ground using mortar and pestle, sieved $(250 \mu \mathrm{m})$, labelled, stored in a tightly closed container, and kept dry in a desiccator $(10 \%$ relative humidity).

2.3. Polarized Optical Microscopy. A small amount ( $0.2 \mathrm{mg})$ of starch powder was placed on a microscope slide $(25.4 \mathrm{~mm} \times 76.2 \mathrm{~mm})$ by using a spatula. The starch was stained with $0.25 \%$ Lugol's solution. The slide was then covered with a coverslip and observed under a compound light microscope (DM 750, Leica Microsystem, Wetzlar, Germany) equipped with a camera set (ICC50 W, Leica Microsystem, Wetzlar, Germany), polarized filter and analyzer. Images of starch granule and hilum were observed and captured. The granule sizes were measured using the ImageJ software (NIH, US).

2.4. Scanning Electron Microscopy (SEM). Structural characteristics of the starch granules were examined with scanning electron microscope Jeol JSM-6400 (Jeol Ltd., Tokyo, Japan) and analyzed with an energy dispersive X-ray analyzer (EDS) PGT Spirit at an acceleration of $20 \mathrm{keV}$. Samples of starch were mounted on aluminium specimen stubs with doublesided adhesive tape and sputtered with a 20-30 nm gold layer using a sputter coater before observation.

2.5. Chemical Properties and Resistant Starch. Macrocomponents (total starch and amylose) and resistant starch were determined using the Megazyme assay kit with given procedures (Megazyme International Ireland Ltd., Bray, Ireland). Microcomponents, i.e., protein, lipid, and phosphorus, were determined the content by following the Official Method of AOAC International [17].

2.6. X-Ray Diffraction. Starch powders were scanned through the $2 \theta$ of $5^{\circ}-45^{\circ}$ using X-ray diffractograms (Xpert Pro MPD, Philips, Netherlands). Traces were obtained using a $\mathrm{Cu}-\mathrm{K} \alpha$ radiation detector with a nickel filter and scintillation counter operating under the following conditions: $40 \mathrm{kV}, 30 \mathrm{~mA}$, scattering slit $25 \mathrm{~nm}, \mathrm{~K}$-Alpha1 wavelength $1.78901 \AA$, KAlpha1 wavelength $1.7929 \AA$, Ratio K-Alpha2/K-Alpha1 0.5 , and scanning rate of $0.02^{\circ} / \mathrm{min}$. The degree of crystallinity of samples was estimated and analyzed following the method of Zhang et al. [15].

2.7. Starch Gelatinization. Thermal properties of starches were studied using differential scanning calorimeter, DSC (Model-823e, Mettler-Toledo, Switzerland). Starch ( 10 mg, dry weight) was placed into a $40 \mu \mathrm{L}$ capacity aluminium pan with the addition of $70 \%$ distilled water to achieve starch-water suspension. The DSC analyzer's calibration was conducted using indium, and an empty aluminium pan was used as a reference. Sample pans were heated from 25 to $120^{\circ} \mathrm{C}$ at the rate of $10^{\circ} \mathrm{C} / \mathrm{min}$. Onset temperature (To), peak temperature $(T p)$, conclusion temperature $(T c)$, and gelatinization enthalpy $(\Delta H)(\mathrm{J} / \mathrm{g}$ dry starch) were determined in triplicate.

2.8. Rheological Behaviour. Rheological properties of starches suspended in distilled water were determined by rotational 
TABLE 1: Starch granule characteristics and size, based on commercial starch by Pomeranz [19].

\begin{tabular}{|c|c|c|c|c|}
\hline Species & Part & $\begin{array}{l}\text { Granules size } \\
(\mu \mathrm{m})\end{array}$ & The shape of starch granule & Hilum \\
\hline \multicolumn{5}{|c|}{ Small starch granule $(3-8 \mu \mathrm{m})$} \\
\hline C. esculenta & Corm & $2.95 \pm 0.47^{\mathrm{de}}$ & Polygonal, irregular, and oval & Centric \\
\hline E. dulcis & Corm & $6.74 \pm 0.56^{\mathrm{bc}}$ & $\begin{array}{l}\text { Big elongated granule, small oval granule, and spherical with smooth } \\
\text { surfaces }\end{array}$ & Centric \\
\hline S. sagittifolia & Corm & $7.53 \pm 0.46^{\mathrm{b}}$ & Round and oval with smooth surfaces & $\begin{array}{l}\text { Centric and } \\
\text { eccentric }\end{array}$ \\
\hline T. bispinosa & Seed & $7.90 \pm 0.44^{\mathrm{b}}$ & Elongated with smooth surfaces & Centric \\
\hline $\begin{array}{l}\text { T. } \\
\text { angustifolia }\end{array}$ & Rhizome & $4.69 \pm 0.46^{\mathrm{cd}}$ & Round and oval with smooth surfaces & Centric \\
\hline $\begin{array}{l}\text { T. } \\
\text { angustifolia }\end{array}$ & Pollen & $2.09 \pm 1.16^{\mathrm{e}}$ & Polygonal, irregular, and oval & Centric \\
\hline \multicolumn{5}{|c|}{ Medium-sized starch granule $(10-25 \mu \mathrm{m})$} \\
\hline N. nucifera & Seed & $9.22 \pm 0.92^{\mathrm{b}}$ & Oval and ellipsoidal with a smooth surface & Centric \\
\hline \multicolumn{5}{|c|}{ Large starch granule $(15-100 \mu \mathrm{m})$} \\
\hline N. nucifera & Rhizome & $20.96 \pm 1.86^{\mathrm{a}}$ & Small oval granules, large longitudinal, rod-shaped granules & $\begin{array}{c}\text { Centric and } \\
\text { eccentric }\end{array}$ \\
\hline
\end{tabular}

Data are mean values of $n=30$ determination \pm standard error, and different superscripts $(\mathrm{a}>\mathrm{b}>\mathrm{c}>\mathrm{d}>\mathrm{e})$ are significantly different $(\mathrm{DMRT}, p<0.05)$.

rheometer (C-DG26.7/QC, RheolabQC, Anton Par Ltd, Germany). $6 \%(w / v)$ suspension of native starches were prepared by dispersing a suitable mass of dried starch granules in distilled water by a ratio of $1: 17$ with constant stirring. The viscosity (mPas) and shear stress $(\mathrm{Pa})$ were determined following the method by Chrungoo and Devi [18].

2.9. Statistical Analysis. The data recorded in all the tables were mean values and standard error. Analysis of variance (1-way ANOVA) was performed for the data and, if significant, followed by a post hoc Duncan's multiple range test (DMRT) $(p<0.05)$ using the SPSS 16.0 Statistical Software Program, IBM, Chicago, IL.

\section{Results and Discussion}

3.1. Starch Granule Morphology. Starch granules of plant species varied in size from $1 \mathrm{~mm}$ up to $100 \mathrm{~mm}$, for taxonomic discrimination to be possible. Nelumbo nucifera rhizome had significantly larger starch granules with $20.96 \mu \mathrm{m}$. In contrast, the smaller granules were in C. esculenta corm and T. angustifolia pollen with 2.95 and $2.09 \mu \mathrm{m}$, respectively (Table 1). Pomeranz [19] categorized the starch granule size based on commercial starch into three groups; large, 15-100 $\mu \mathrm{m}$ (potato starch), medium-sized, 10-25 $\mu \mathrm{m}$ (maize or corn starch), and small, 3-8 $\mu \mathrm{m}$ (rice starch). From the starch classification, $N$. nucifera rhizome possesses large starch granules while $N$. nucifera seed has medium-sized starch granules that ranged 8.11$17.78 \mu \mathrm{m}$. The corms of C. esculenta, E. dulcis and S. sagittifolia, T. bispinosa seed, T. angustifolia rhizome, and pollen have small starch granules ranging $0.4-13.44 \mu \mathrm{m}$. The size of starch granules affects starch granules gels and paste performance as the larger the granule, the faster it swells, due to less molecular bonding than smaller granule [20]. For example, potato starch possessed a large granule $(15-100 \mu \mathrm{m})$, which resulted in faster gelatinization range $\left(56-69^{\circ} \mathrm{C}\right)$. In contrast, the smaller granules of regular corn $(5-25 \mu \mathrm{m})$ resulted in a slightly slower gelatinization range with $62-80^{\circ} \mathrm{C}$ (Pomeranz, 2019). In this present study, a large starch granule of $N$. nucifera rhizome gelatinizes faster than others. Besides, Pomeranz [19] also reported that small starch granules are relatively rare, which are suitable in dusting starches used in candy dusting, cosmetics, filling agent for the biodegradable polyethylene film, and tyre molding release agents. Also, in taro, its small starch has been proven to be easily digested, hence a potential commercial value in baby foods and patients with gastrointestinal problems for ease of bioassimilation [21]. The granular structure and shape were also varied, as shown in Figure 1. Small granules of C. esculenta corm and T. angustifolia had predominantly polygonal and irregular shapes with few oval shapes. In contrast, the larger granules normally were observed with predominantly longitudinal and rod-shaped such as in N. nucifera rhizome. Tester et al. [22] reported that starch granules were as simple or compound. Some plant contains compound granules (C. esculenta corm and $N$. nucifera rhizome) due to the fusing of different granules developing simultaneously within a single amyloplast during biosynthesis [23]. The rest of the species were as simple granules.

Besides, some starch granules may still attach to other nonstarch components like fiber, lipid, or protein fragments despite undergoing isolating process, as shown in T. angustifolia seed starch (Figure 1(h)). According to Svihus et al. [24], these components, especially lipid and protein associated with granules, may influence digestion by reducing the contact between starch and digestive enzymes, thus slowing the swelling of the granules and gelatinization process. The position of the hilum or Maltese cross was also considered one of the unique identifications as it described the nucleus around which the starch form [25]. All the aquatic macrophytes starch samples showed distinct Maltese cross across the 


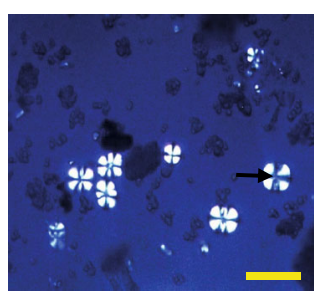

(a)

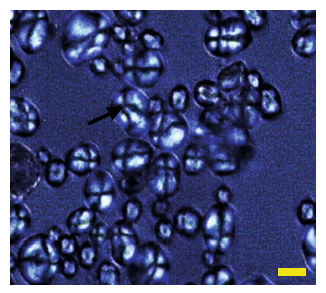

(e)

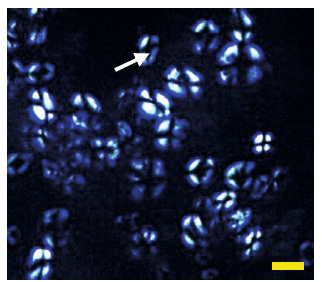

(i)

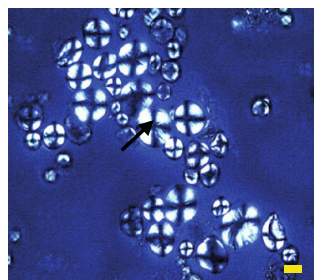

(m)

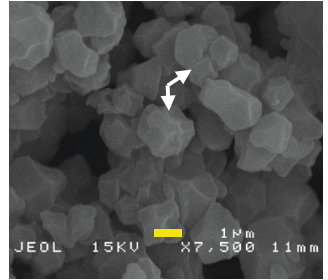

(b)

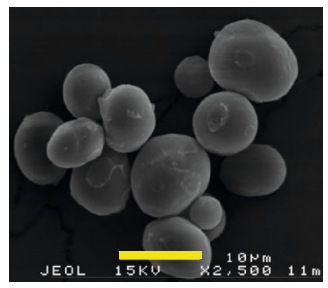

(f)

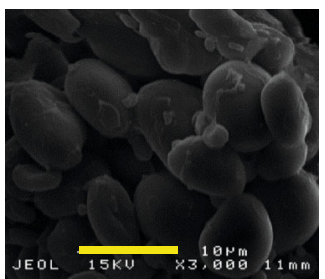

(j)

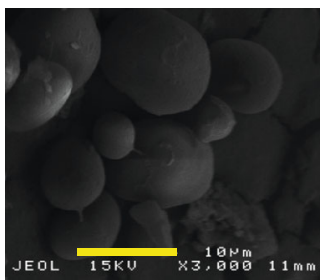

(n)

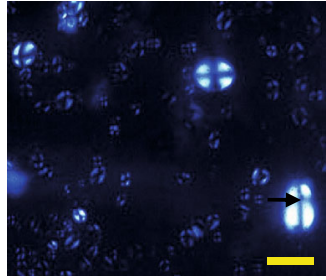

(c)

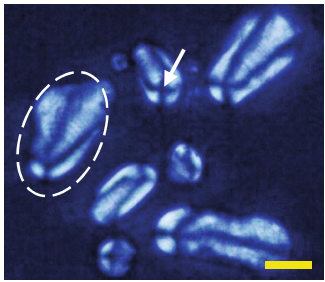

(g)

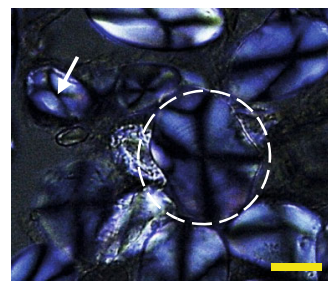

(k)

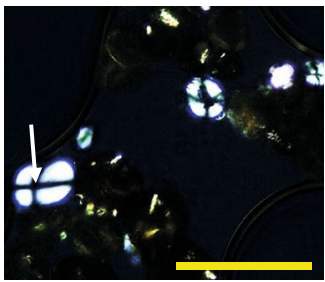

(o)

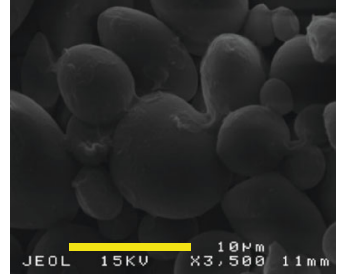

(d)

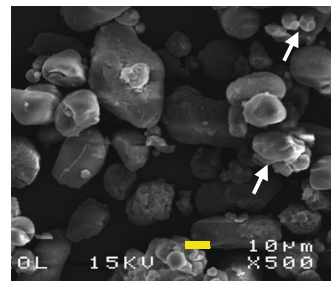

(h)

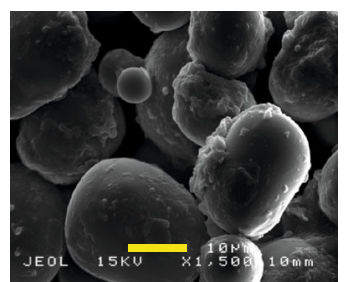

(1)

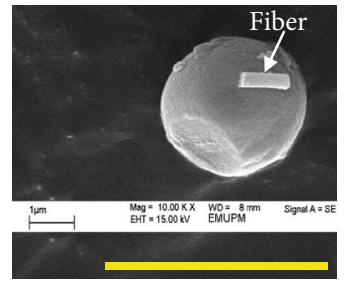

(p)

FIgURE 1: Starch granules of aquatic macrophytes captured $(a-h)$ under polarized microscope, 40X magnification and $(b, d, f, h)$, under scanning electron microscope: (a, b) Colocasia esculenta corm, (c, d) Eleocharis dulcis corm, (e, f) Sagittaria sagittifolia corm, (g, h) Nelumbo nucifera rhizome, (i, j) Nelumbo nucifera seed, $(\mathrm{k}, \mathrm{l})$ Trapa bispinosa seed, $(\mathrm{m}, \mathrm{n})$ Typha angustifolia rhizome, and (o, $\mathrm{p})$ Typha angustifolia seed. The yellow bar scale represents $10 \mu \mathrm{m}$ length and $1 \mu \mathrm{m}$ length for a, c, e, g and b, d, f, h, respectively. Arrows in the polarized image indicate the hilum (Maltese cross).

hilum when viewed under a polarized microscope. Roundand oval-shaped granules were with centric hilum, such as in corm of C. esculenta and E. dulcis, and rhizome of T. angustifolia. On the other hand, hilum was observed eccentrically at the small end of the elongated granules of $S$. sagittifolia corm and N. nucifera rhizome. Large granule like potato starch displayed pronounced striations around the central hilum where it is the botanical point of origin for the granule to grow [19], which can be seen in the rhizome of N. nucifera and the seed of T. bispinosa (circled granules) even though the layer not as distinct as reported in potato.

3.2. Chemical Properties. The starch paste behaviour and functionality depend on the composition of amylose and amylopectin and the microcomponent as such affects the final food quality. Table 2 shows that the moisture content of the starch flours from the present study is in the range between $8.91 \%$ of T. angustifolia pollen and $17.23 \%$ of E. dulcis corm starch. A higher total starch was in corm samples, including E. dulcis (90.87\%), C. esculenta (82.35\%), and S. sagittifolia (71.71\%), whereas the $T$. angustifolia pollen has a significantly least starch content $(7.02 \%)$. Based on previous studies, Typha sp. generally had low starch contents ranging between $13.01 \%$ and $14.5 \%$ compared to other commercial starch such as Zea mays $(22.40 \%)[26,27]$. The composition of amylose and amylopectin gives variable effects of starch swelling capacity, water solubility, water-binding capacity, and microscopic characteristics, hence carried different industrial applications [28]. Normal starch generally contains $75 \%$ of amylopectin and $25 \%$ of amylose, while waxy starch contains $<15 \%$ amylose and 20 $35 \%$ amylopectin. Regular starch and high-amylose starches contain $>40 \%$ amylose [22]. The present study shows that $N$. nucifera seed had high-amylose content with $71.45 \%$, whereas T. angustifolia pollen and S. sagittifolia corm were categorized as regular starches with an amylose content of $36.47 \%$ and $19.80 \%$, respectively. The rest were classified as waxy starch, 
TABLE 2: Total starch, proximate compositions and phosphorus content of freshwater macrophytes starches.

\begin{tabular}{lcccccc}
\hline Species & Total starch (\%) & Amylose (\%) & Moisture (\%) & Protein (\%) & Lipid (\%) & Phosphorus (ppm) \\
\hline C. esculenta corm & $82.35 \pm 1.18^{\mathrm{b}}$ & $10.61 \pm 0.13^{\mathrm{e}}$ & $10.70 \pm 0.08^{\mathrm{cd}}$ & $5.67 \pm 0.03^{\mathrm{d}}$ & $0.49 \pm 0.08^{\mathrm{d}}$ & $0.04 \pm 0.01^{\mathrm{bc}}$ \\
E. dulcis corm & $90.87 \pm 1.56^{\mathrm{a}}$ & $11.48 \pm 0.60^{\mathrm{e}}$ & $17.23 \pm 0.26^{\mathrm{a}}$ & $4.39 \pm 0.19^{\mathrm{e}}$ & $0.24 \pm 0.15^{\mathrm{d}}$ & $0.13 \pm 0.01^{\mathrm{a}}$ \\
S. sagittifolia corm & $71.71 \pm 1.83^{\mathrm{c}}$ & $19.80 \pm 0.47^{\mathrm{c}}$ & $11.91 \pm 0.25^{\mathrm{bc}}$ & $3.06 \pm 0.02^{\mathrm{f}}$ & $0.61 \pm 0.21^{\mathrm{d}}$ & $0.02 \pm 0.00^{\mathrm{c}}$ \\
T. bispinosa seed & $49.56 \pm 0.61^{\mathrm{e}}$ & $8.83 \pm 0.10^{\mathrm{f}}$ & $14.43 \pm 0.16^{\mathrm{ef}}$ & $26.47 \pm 0.83^{\mathrm{a}}$ & $1.13 \pm 0.13^{\mathrm{c}}$ & $0.08 \pm 0.01^{\mathrm{abc}}$ \\
T. angustifolia rhizome & $66.02 \pm 1.68^{\mathrm{d}}$ & $13.51 \pm 0.11^{\mathrm{d}}$ & $11.86 \pm 0.16^{\mathrm{bc}}$ & $4.86 \pm 0.51^{\mathrm{de}}$ & $3.87 \pm 0.16^{\mathrm{a}}$ & $0.09 \pm 0.06^{\mathrm{abc}}$ \\
T. angustifolia pollen & $7.02 \pm 0.05^{\mathrm{f}}$ & $36.47 \pm 0.49^{\mathrm{b}}$ & $8.91 \pm 0.57^{\mathrm{f}}$ & $15.70 \pm 0.14^{\mathrm{b}}$ & $3.23 \pm 0.12^{\mathrm{b}}$ & $0.10 \pm 0.01^{\mathrm{ab}}$ \\
N. nucifera seed & $67.69 \pm 0.13^{\mathrm{d}}$ & $71.45 \pm 1.04^{\mathrm{a}}$ & $12.93 \pm 0.13^{\mathrm{b}}$ & $7.24 \pm 0.20^{\mathrm{c}}$ & $2.96 \pm 0.24^{\mathrm{b}}$ & $0.05 \pm 0.01^{\mathrm{bc}}$ \\
N. nucifera rhizome & $66.00 \pm 1.68^{\mathrm{d}}$ & $7.63 \pm 0.21^{\mathrm{f}}$ & $11.84 \pm 0.17^{\mathrm{bc}}$ & $7.96 \pm 0.05^{\mathrm{c}}$ & $0.42 \pm 0.12^{\mathrm{d}}$ & $0.05 \pm 0.01^{\mathrm{bc}}$ \\
\hline
\end{tabular}

Data are mean values of $n=3$ determination \pm standard error, and different superscripts $(\mathrm{a}>\mathrm{b}>\mathrm{c}>\mathrm{d}>\mathrm{e}>\mathrm{f}>\mathrm{g}$ ) are significantly different (DMRT, $p<0.05)$.

ranging from $7.63 \%$ in N. nucifera rhizome to $13.51 \%$ in $T$. angustifolia rhizome. According to Eltaboni et al. [29], starch granules may contain amylose up to $80 \%$ as observed in the N. nucifera seed starch of the present study. In addition, a wide range of amylose content was observed in 46 lotus roots starches from $2.31 \%$ of Lianhu wild lotus to $60.52 \%$ of Jianxuan-35 hao lotus root [30]. A starch with high-amylose content usually had a small and narrow size range with nonsymmetrically shape granules [31]. Similarly, such characteristics of starch granules of $N$. nucifera seed and T. angustifolia pollen also possess a higher amylose content. The high amylose of $N$. nucifera seed starch can be applied as a gelling agent or in the biodegradable plastic film industry. The chemical properties of the less-branched amylose molecule also provide beneficial effects to human health. Meals prepared with high amylose slow the rate of digestion, as it possesses the higher crystallinity which generated a postprandial glucose response in the attributed blood and lessened the fasting concentration of triacylglycerol and cholesterol [32]. Consequently, highamylose N. nucifera seed starch may reduce the blood glucose and insulin level and enhance the body's fat burning.

In contrast, waxy starch with higher amylopectin which possesses branched and long chain length greater than 30 chains yielded higher molecular weight. Thus, this branched chain hindered each particle from reassociating and formed an ordered structure that resulted in weaker hydrogen bonding and the strength of the gel [20]. Amylopectin with the clustered structures reduced retrogradation, gelation, and syneresis (loss of water). However, they are better at building viscosity and the production of more slimy paste. This suggested that waxy starch in this study are suitable in making soft-textured food such as dessert-like products, baby foods, gravies, sauces, and thickening soup due to its excellent water retention properties, porous texture, and stickiness criteria [33]. Generally, foods with higher amylopectin have a higher glycemic index as they are readily digestible and absorbed after consumed. Thus, it is advisable to opt for food lower in amylopectin to prevent the raising of blood sugar, insulin, and cholesterol levels. However, recent studies show that scientists have devised various ways to minimise food digestibility for waxy starches via an enzymatic process, encapsulation, extrusion cooking, recrystallization, and starch chemical modification [33]. Under this new development, the modified waxy starches such as wheat, rice, and maize have great potential as novel functional food ingredients, which also equally applied for waxy aquatic macrophytes starches.

The minor components analysis showed higher protein accumulated in T. bispinosa seed (26.47\%) followed by $T$. angustifolia pollen (15.70\%) starches, whereas the least was from S. sagittifolia corm with $3.06 \%$. Higher lipid contents were in T. angustifolia rhizome and pollen $(3.87 \%$ and $3.23 \%$, respectively) and N. nucifera seed (2.96\%). According to Tester et al. [22], proteins and lipids can limit the starch functionality as they can associate with starch granule on the surface and internal components. Protein contents also influenced the pasting activity as higher protein will build up the interaction's binding forces, thus reducing the pasting temperature [34]. The presence of flexible protein molecules may reduce the water's surface tension and increase the foaming tendency, which is important in maintaining the structure and texture of food products such as baked goods and ice cream [34]. However, higher protein may also have undesired side effects. It can produce browning and off-flavor in foods due to its positive reaction with major food components such as reducing sugars, polyphenols, fats, and other oxidation products [25]. Svihus et al. [24] reported that smaller granules usually have higher lipid contents, which are also observed in small granules of T. angustifolia pollen and rhizome. Starchlipid compositions used in several applications, such as stabilizers and thickener agents, reduced starch stickiness, dough conditioners, enhanced freeze-thaw stability, detain bread, and biscuit staling and bread crumb softener [35].

3.3. Resistant and Nonresistant Starch. Table 3 represents resistant (RS) and nonresistant starch (non-RS) content in the freshwater macrophytes starch samples in comparison with previous studies. Higher RS accumulated in the rhizome part of N. nucifera and T. angustifolia (39.34\% and 37.19\%, respectively). These values are comparable with $C$. esculenta (35.19\%) and Trapa sp. (36.80\%) starches from previous studies [35, 36]. Lower RS was observed in T. bispinosa seed with $6.92 \%$, whereas S. sagittifolia corm starch had a comparable value of RS (35.39\%) and non-RS (37.37\%). Besides, C. esculenta starch had significantly higher non-RS compared to 
TABLE 3: Resistant and nonresistant starch of the present study in comparison with other previous studies.

\begin{tabular}{lccc}
\hline Species/part & Resistant starch (\%) & Nonresistant starch (\%) & References \\
\hline C. esculenta corm & $18.35 \pm 0.47$ & $64.87 \pm 2.63$ & Present study \\
E. dulcis corm & $37.41 \pm 0.21^{\mathrm{a}}$ & $45.29 \pm 1.25^{\mathrm{c}}$ & Present study \\
S. sagittifolia corm & $35.09 \pm 0.53^{\mathrm{b}}$ & $37.37 \pm 0.98^{\mathrm{d}}$ & Present study \\
T. bispinosa seed & $6.92 \pm 1.58^{\mathrm{f}}$ & $56.94 \pm 1.35^{\mathrm{b}}$ & Present study \\
T. angustifolia rhizome & $37.19 \pm 1.05^{\mathrm{ab}}$ & $21.10 \pm 0.76^{\mathrm{f}}$ & Present study \\
T. angustifolia pollen & $9.65 \pm 0.08^{\mathrm{e}}$ & $3.52 \pm 0.22^{\mathrm{g}}$ & Present study \\
N. nucifera seed & $27.94 \pm 0.37^{\mathrm{c}}$ & $44.36 \pm 0.34^{\mathrm{c}}$ & Present study \\
N. nucifera rhizome & $39.34 \pm 0.06^{\mathrm{a}}$ & $27.69 \pm 0.82^{\mathrm{e}}$ & Present study \\
\hline
\end{tabular}

Previous studies

Aquatic macrophytes starch

$\begin{array}{lcl}\text { C. esculenta } & 1.99 \\ \text { C. esculenta } & 2.11 \\ \text { C. esculenta } & 2.26 \\ \text { C. esculenta } & 35.19 \\ \text { C. esculenta } & 44.10 \\ \text { C. esculenta } & 27.50 \\ \text { C. esculenta } & 4.12 \\ \text { Trapa sp. } & 41.50 \\ \text { Trapa sp. } & 36.80 \\ \text { E. dulcis } & 8.05 \\ \text { N. nucifera rhizome } & 2.10 \\ \text { N. nucifera seed } & 19.70\end{array}$

$\begin{array}{ll}- & {[43]} \\ - & {[43]} \\ - & {[43]} \\ 35.73 & {[44]} \\ - & {[36]} \\ - & {[36]} \\ 59.61 & {[45]} \\ - & {[36]} \\ - & {[36]} \\ - & {[36]} \\ - & {[36]} \\ - & {[36]}\end{array}$

Commercialized starch

$\begin{array}{lcr}\text { Dioscorea alata } & 22.48 & 18.85 \\ \text { Ipomea batatas } & 0.97 & 75.55 \\ \text { I. batatas } & 28.90 & - \\ \text { I. batatas } & 3.19 & - \\ \text { Zea mays } & 7.83 & - \\ \text { Solanum tuberosum } & 79.30 & \\ \text { Manihot esculenta } & 80.80 & 55.99 \\ \text { M. esculenta } & 9.69 & 72.04 \\ \text { Oryza sativa (waxy) } & 2.72 & \end{array}$

$\begin{array}{ll}18.85 & {[44]} \\ 75.55 & {[44]} \\ - & {[36]} \\ 49.35 & {[45]} \\ - & {[36]} \\ - & {[36]} \\ & {[36]} \\ 55.99 & {[45]} \\ 72.04 & {[45]}\end{array}$

Data are mean values of $n=3$ determination \pm standard error, and different superscripts $(\mathrm{a}>\mathrm{b}>\mathrm{c}>\mathrm{d}>\mathrm{e}>\mathrm{f}$ ) are significantly different $(\mathrm{DMRT}, p<0.05)$.

others. Generally, high-amylose starch possessed high RS; however, in the present study, the $N$. nucifera seed had higher digestible starch (44.36\%) compared to its RS (27.94\%). The present study showed that RS was higher mostly in the rhizome part compared to others due to their B-type crystallinity. Densely packed B-type and CB-type crystallinity patterns are poorly susceptible to hydrolysis containing higher RS compared to A-type [37]. They further reported that high-amylose starch tends to possess higher $\mathrm{RS}$ as studied in cereal starch due to low digestibility. This factor can benefit the consumer interested in a lowcarbohydrate dieting regime as slow digestion of RS (digestion occurs after 5-7 hours) can lower insulin and glycemic response and accelerate the satiation level [38]. The variations in resistant starch content between starches of the same species with previous studies (Table 3 ) were due not only to the chemical parameters (e.g., amylose and phosphorus contents) but also to the physical and structural characteristics such as shape and of granule, molecular interaction and crystallinity pattern of each plant [39]. Also, RS brings benefits in the functional properties of starch in terms of granules swelling, viscosity paste, the formation of gel, and waterbinding capacity [37]. The fine, white, and tasteless characteristic of RS particles and its crispness properties make it easy to process and improve the texture, appearance, and mouthfeel in the final product. Silvi et al. [40] reported that $\mathrm{RS}$ is an excellent dietary supplement because it can increase good prebiotic microorganisms and reduce the population of harmless Enterobacteria in the colon. However, excessive consumption of RS, mainly the raw starch, will have adverse 


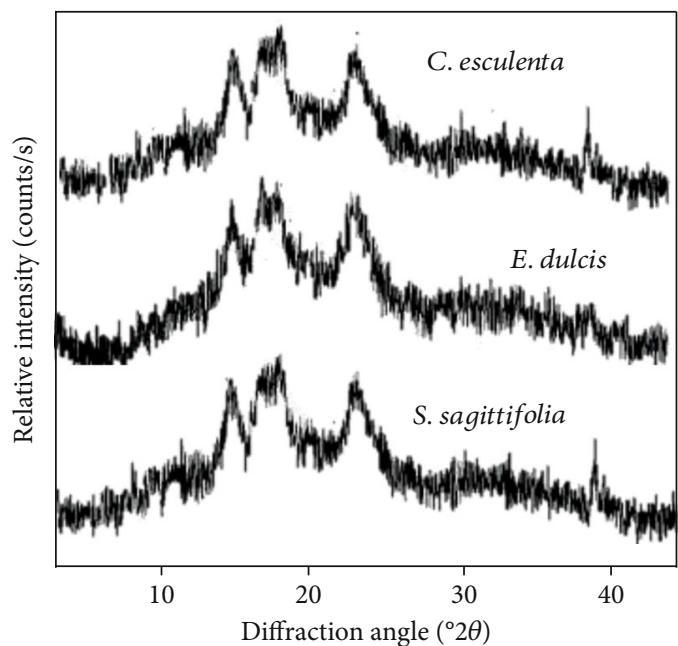

(a)

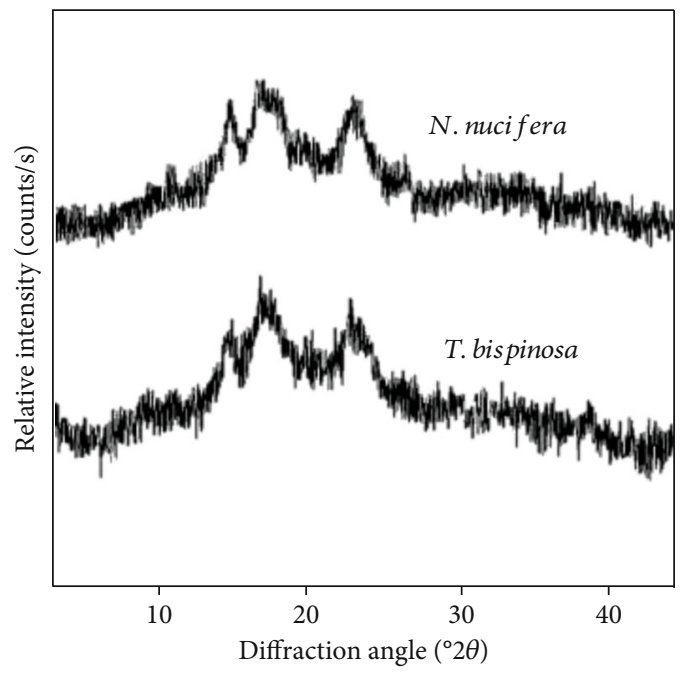

(c)

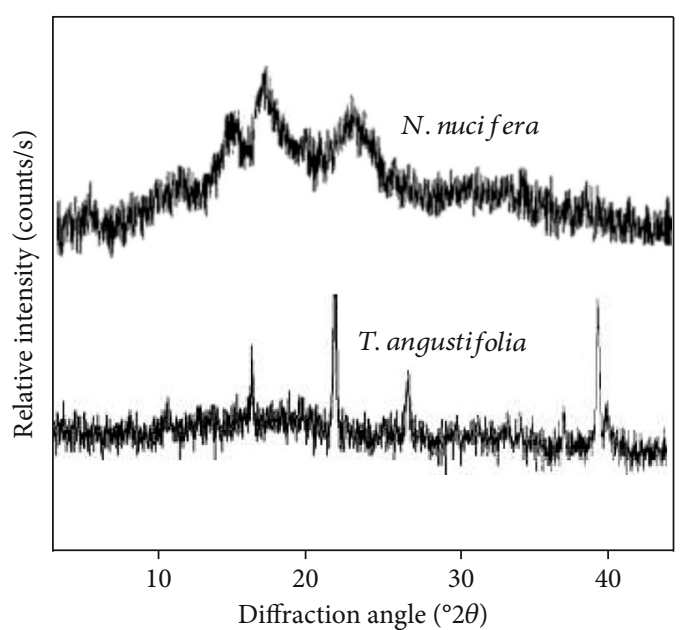

(b)

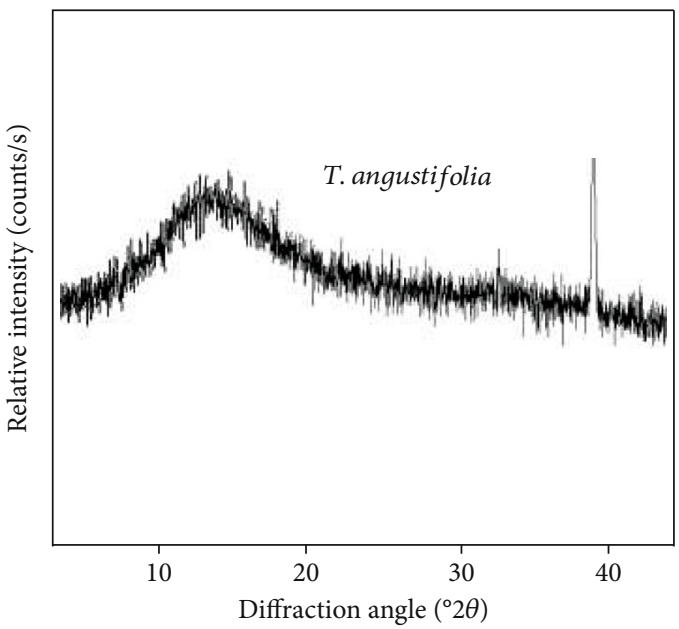

(d)

FIGURE 2: XRD pattern of aquatic macrophytes based on their parts. (a) Corm, (b) rhizome, (c) seed, and (d) pollen samples.

effects on gastrointestinal performance such as bloating, flatulence, and borborygmi (stomach rumble due to fluid and gas movement in the intestines) and diarrhea. According to Food and Agriculture Organization (FAO) and World Health Organization (WHO), adequate intakes for total fiber are differed based on gender, with $38 \mathrm{~g}$ for men, while $25 \mathrm{~g}$ for women [41]. Baghurst et al. [42] reported total intakes of approximately 30-40 g per day of RS consumed in developing countries. A $20 \mathrm{~g}$ of RS per day consumption is the recommendation by Australia's Commonwealth Scientific and Industrial Research Organization (CSIRO). This amount is much higher than those in Europe of 3-6 g/day due to accessibility in bread and cereals [42]

3.4. Starch Crystallinity. The XRD profiles of aquatic macrophytes are presented in Figure 2, which exhibited wellresolved and intense peaks based on their parts. There are three types of XRD patterns categorized based on their absence of a peak at a certain different angle. The A-type X- ray pattern is characterized with a strong double peak at $2 \theta$ $\approx 17^{\circ}$ and $18^{\circ}$, and strong diffraction peak at $2 \theta \approx 15^{\circ}$ and $23^{\circ}$ , whereas the B-type pattern showed pronounced peak diffraction peak at $2 \theta \approx 15^{\circ}$ and $17^{\circ}$, as well broad diffraction peak at $2 \theta \approx 23^{\circ}$, with smalls peak around $15^{\circ}, 20^{\circ}, 22^{\circ}$, and $24^{\circ} 2 \theta[22,46]$. The C-type is a mixture of A-type and Btype which can be further categorized to $\mathrm{C}_{\mathrm{A}}$-type if closer to A-type and $\mathrm{C}_{\mathrm{B}}$-type if closer to B-type, or prominent $\mathrm{C}$ type if the proportion of $\mathrm{A}$ - and B-type allomorphs are equal [46]. According to Kim et al. [47], the X-ray diffraction pattern indicates the parallel stranded double helices where Atype structure is more compact than the looser crystallinity of B-type with a more open structure. Furthermore, seed starches generally possessed A-type pattern, whereas tuber and high-amylose cereal starches mostly showed B-type patterns [48].

Based on the present study, corm samples and seed of $N$. nucifera displayed A-type with the presence of peaks intensity at $2 \theta \approx 15^{\circ}$ and $23^{\circ}$ and strong doublet around $17^{\circ}$ and $18^{\circ} 2 \theta$ 
TABLE 4: Degree of crystallinity and X-ray pattern of native starch extracted from aquatic macrophytes.

\begin{tabular}{|c|c|c|c|c|c|c|c|c|c|c|}
\hline \multirow{2}{*}{ Species/part } & \multirow{2}{*}{$\mathrm{X}$-ray pattern } & \multirow{2}{*}{ Relative crystallinity (\%) } & \multicolumn{8}{|c|}{ Different peak intensity at $2 \theta$ value (\%) } \\
\hline & & & $5^{\circ}$ & $15^{\circ}$ & $17^{\circ}$ & $18^{\circ}$ & $20^{\circ}$ & $22^{\circ}$ & $23^{\circ}$ & $24^{\circ}$ \\
\hline C. esculenta corm & A & 36.91 & - & 31.35 & 29.10 & 31.77 & - & - & 21.16 & - \\
\hline E. dulcis corm & A & 21.34 & - & 29.05 & 36.50 & 28.87 & - & - & 32.82 & - \\
\hline S. sagittifolia corm & A & 21.28 & - & 27.37 & 30.15 & 22.83 & - & - & 18.66 & - \\
\hline T. bispinosa seed & $\mathrm{C}_{\mathrm{A}}$ & 35.59 & - & 34.86 & 57.16 & 47.52 & 24.73 & - & 33.72 & - \\
\hline T. angustifolia rhizome & $\mathrm{C}_{\mathrm{B}}$ & 15.56 & - & 3.07 & 3.96 & - & 15.80 & - & - & 2.77 \\
\hline T. angustifolia pollen & $\mathrm{C}_{\mathrm{B}}$ & 15.27 & 1.99 & 3.05 & - & - & - & - & - & - \\
\hline N. nucifera seed & $\mathrm{A}$ & 29.20 & - & 27.29 & 36.97 & 21.95 & - & - & 20.18 & - \\
\hline N. nucifera rhizome & $\mathrm{C}_{\mathrm{B}}$ & 24.20 & 5.96 & 16.71 & 34.16 & - & - & - & 18.24 & - \\
\hline
\end{tabular}

TABLE 5: Thermal properties of native starch extracted from aquatic macrophytes.

\begin{tabular}{|c|c|c|c|c|c|c|}
\hline Species/part & $T_{o}\left({ }^{\circ} \mathrm{C}\right)$ & $T_{p}\left({ }^{\circ} \mathrm{C}\right)$ & $T_{c}\left({ }^{\circ} \mathrm{C}\right)$ & $\Delta H_{\text {gel }}\left(\mathrm{J} \mathrm{g}^{-1}\right)$ & PHI & $T_{r}\left({ }^{\circ} \mathrm{C}\right)$ \\
\hline C. esculenta corm & $50.91 \pm 0.09^{\mathrm{d}}$ & $89.85 \pm 0.02^{\mathrm{d}}$ & $119.54 \pm 0.03^{\mathrm{a}}$ & $13.73 \pm 0.00^{c}$ & $0.71 \pm 0.0^{\mathrm{d}}$ & $38.94 \pm 0.07^{\mathrm{c}}$ \\
\hline E. dulcis corm & $53.14 \pm 0.04^{c}$ & $91.35 \pm 0.04^{c}$ & $119.58 \pm 0.01^{\mathrm{a}}$ & $12.81 \pm 0.00^{\mathrm{f}}$ & $0.67 \pm 0.00^{\mathrm{e}}$ & $38.21 \pm 0.03^{\mathrm{d}}$ \\
\hline S. sagittifolia corm & $58.17 \pm 0.02^{\mathrm{b}}$ & $94.45 \pm 0.02^{\mathrm{b}}$ & $119.34 \pm 0.04^{\mathrm{c}}$ & $7.31 \pm 0.01^{\mathrm{g}}$ & $0.40 \pm 0.00^{\mathrm{g}}$ & $36.28 \pm 0.01^{\mathrm{f}}$ \\
\hline T. bispinosa seed & $50.26 \pm 0.03^{\mathrm{e}}$ & $89.83 \pm 0.04^{\mathrm{d}}$ & $116.96 \pm 0.03^{\mathrm{d}}$ & $13.15 \pm 0.02^{\mathrm{d}}$ & $0.66 \pm 0.00^{\mathrm{f}}$ & $39.57 \pm 0.03^{\mathrm{a}}$ \\
\hline T. angustifolia rhizome & $58.73 \pm 0.01^{\mathrm{a}}$ & $96.02 \pm 0.00^{\mathrm{a}}$ & $119.56 \pm 0.00^{\mathrm{a}}$ & $3.85 \pm 0.00^{\mathrm{h}}$ & $0.21 \pm 0.00^{\mathrm{h}}$ & $37.28 \pm 0.00^{\mathrm{e}}$ \\
\hline T. angustifolia pollen & $41.63 \pm 0.00^{\mathrm{h}}$ & $74.62 \pm 0.00^{\mathrm{g}}$ & $99.89 \pm 0.00^{f}$ & $18.66 \pm 0.01^{b}$ & $1.13 \pm 0.00^{\mathrm{a}}$ & $33.00 \pm 0.01^{h}$ \\
\hline N. nucifera seed & $46.85 \pm 0.04^{\mathrm{g}}$ & $86.26 \pm 0.04^{\mathrm{e}}$ & $119.45 \pm 0.03^{b}$ & $19.93 \pm 0.02^{\mathrm{a}}$ & $1.01 \pm 0.01^{\mathrm{b}}$ & $39.41 \pm 0.05^{\mathrm{b}}$ \\
\hline N. nucifera rhizome & $50.13 \pm 0.03^{\mathrm{f}}$ & $84.07 \pm 0.02^{\mathrm{f}}$ & $115.15 \pm 0.05^{\mathrm{e}}$ & $13.12 \pm 0.02^{\mathrm{e}}$ & $0.77 \pm 0.00^{c}$ & $33.94 \pm 0.03^{g}$ \\
\hline
\end{tabular}

Data are mean values of $n=3$ determination \pm standard error, and different superscripts $(a>b>c>d>e>f>g>h>i>j)$ are significantly different $($ DMRT, $p<0.05$ ).

(Table 4), consistent with the previous studies of arrowhead [49], Chinese water chestnut [50], taro [51], and lotus seed [48]. Trapa bispinosa exhibits A-type characteristic with small peak intensity at $2 \theta \approx 20^{\circ}(24.73 \%)$ which results in $\mathrm{C}_{\mathrm{A}}$-type similar to the water caltrop species (T. bispinosa, T. quadrispinosa, T. pseudoinisa, and T. taiwanensis) of previous studies [12, 52-54]. Furthermore, all the rhizome parts and T. angustifolia pollen starch exhibited $\mathrm{C}_{\mathrm{B}}$-type crystallinity with peaks at $5^{\circ}, 20^{\circ}$, and $24^{\circ} 2 \theta$ (5.96). Both B- $[55,56]$ (additional) and Ctype $[48,57]$ XRD patterns in lotus rhizome suggest that temperature and other factors influence the crystalline order of lotus rhizome [56]. The XRD pattern of cattail rhizome is contrasting with previous literature in which there was the presence of $\mathrm{A}$ - and B-type XRD; however, higher B-type allomorphs were reported compared to A-type [14]. The XRD pattern of rhizome and pollen of cattails in the present study is poor based on their peak intensity values, caused by other impurities in starch granules.

A relatively higher crystallinity was in C. esculenta corm (36.91\%), followed by T. bispinosa seed (35.59\%). There was a lower relative crystallinity in $T$. angustifolia pollen (15.27\%) and rhizome (15.56\%). The value of relative crystallinity is directly proportional to the amylose content. It expends higher relative crystallinity in the waxy starch of $C$. esculenta corm and T. bispinosa. The lower amylose content reduced the disruption of crystalline nature and the amorphous region within the starch granules [57].

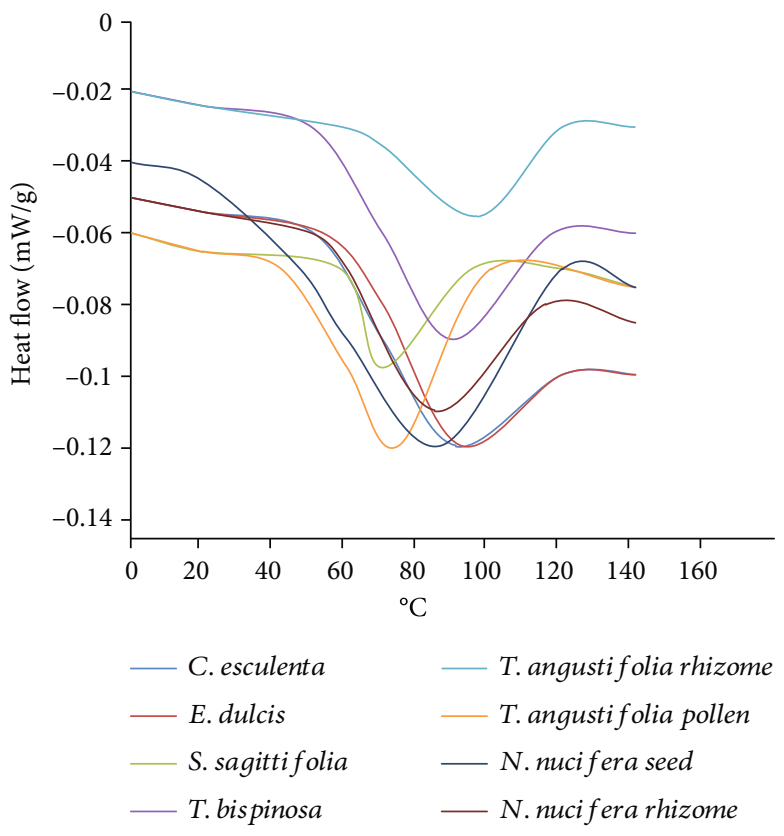

FIgURE 3: DSC curves of aquatic macrophytes starches.

3.5. Thermal Properties. Table 5 shows a summary of the thermal properties results for the starch samples. The starches gave well-defined single endotherms, where the gelatinization onset (To), peak $(T p)$, and conclusion $(T c)$ temperatures of the 
TABLE 6: Rheological behaviour of freshwater macrophytes starches.

\begin{tabular}{lcccc}
\hline Species/part & Temp. $\left({ }^{\circ} \mathrm{C}\right)$ & 1st rotation & Viscosity (mPa s)/shear stress $(\mathrm{Pa})$ & 2nd rotation \\
\hline C. esculenta corm & 32.9 & $46.2 / 71.71$ & $42.7 / 66.25$ & $40.7 / 63.1$ \\
E. dulcis corm & 32.7 & $27.6 / 42.86$ & $26 / 40.36$ & $25.4 / 38.21$ \\
S. sagittifolia corm & 32.7 & $28.4 / 44.02$ & $26.5 / 41.16$ & $24.3 / 38.90$ \\
T. bispinosa seed & 32.4 & $8.8 / 13.72$ & $8.8 / 13.58$ & $8.0 / 13.49$ \\
T. angustifolia rhizome & 32.6 & $8.0 / 12.37$ & $8.1 / 12.89$ & $8.0 / 12.89$ \\
T. angustifolia pollen & 32.4 & $3.2 / 4.93$ & $3.0 / 4.68$ & $2.9 / 4.45$ \\
N. nucifera seed & 33.0 & $28.0 / 43.45$ & $25.7 / 39.83$ & $23.8 / 35.4$ \\
N. nucifera rhizome & 33.0 & $40.9 / 63.35$ & $37.2 / 57.72$ & $34.8 / 51.2$ \\
\hline
\end{tabular}

aquatic macrophytes starches ranged $41.62-58.74^{\circ} \mathrm{C}, 74.62-$ $96.02^{\circ} \mathrm{C}$, and $99.89-119.59^{\circ} \mathrm{C}$, respectively (Figure 3). In contrast, gelatinization enthalpies $(\Delta H)$ ranged $3.85-19.95 \mathrm{Jg}^{-1}$. Higher To and Tp were observed for T. angustifolia rhizome starch $\left(58.73^{\circ} \mathrm{C}\right.$ and $\left.96.02^{\circ} \mathrm{C}\right)$, while the lower results were obtained for $T$. angustifolia pollen starch $\left(41.63^{\circ} \mathrm{C}\right.$ and $74.62^{\circ} \mathrm{C}$ ), respectively. The higher $T c$ value was observed for S. sagittifolia corm $\left(119.58^{\circ} \mathrm{C}\right), \quad T$. angustifolia rhizome $\left(119.56^{\circ} \mathrm{C}\right)$, and C. esculenta corm $\left(119.54^{\circ} \mathrm{C}\right)$ starch, while the lower $T c$ was for $T$. angustifolia pollen starch $\left(99.89^{\circ} \mathrm{C}\right)$. On average, the gelatinization temperature range $(\mathrm{Tr})$ and $\mathrm{PHI}$ values of the native starches' samples were $36.45^{\circ} \mathrm{C}$ and 0.61 , respectively. Temperature ranges from $39.57^{\circ} \mathrm{C}$ in $\mathrm{T}$. bispinosa seed to $39.41^{\circ} \mathrm{C}$ in $N$. nucifera seed. The starch granules size, crystallinity degree, amylose-amylopectin ratio, and the amylopectin branch's size influence the To and $T p$ values [50]. In this present study, a higher To and $T p$ were in $T$. angustifolia rhizome, $58.73^{\circ} \mathrm{C}$ and $96.02^{\circ} \mathrm{C}$, respectively. The formation of amylose and lipid complex in starch is insoluble in water. A higher temperature is required to dissociate the formation and increase the individual granules' swelling to diffuse out the amylose from swollen granules [58]. On the other hand, the Tc was observed higher in most of the smaller granules of E. dulcis corm $\left(119.58^{\circ} \mathrm{C}\right)$, T. angustifolia rhizome $\left(119.56^{\circ} \mathrm{C}\right)$, and C. esculenta corm $\left(119.54^{\circ} \mathrm{C}\right)$. The small-sized granules contain a more significant number of granules per unit weight, which needed higher temperatures to disintegrate the starch particles into paste [9]. Tester and Morrison [59] explained that gelatinization enthalpy $(\Delta H)$ reflects the loss of molecular order within the granules. The high $\Delta H$ lowers the starch crystallinity degree (quality and quantity of crystallites). PHI measured the gelatinization uniformity. The $\Delta H$ is generally associated with double helices of amylopectin chains. A higher amylopectin content result in higher $\Delta H$. However, the present study showed that higher $\Delta H$ and PHI were in starch with higher amylose content such as $N$. nucifera seed $\left(19.93 \mathrm{Jg}^{-1}, 1.01\right)$ and $T$. angustifolia pollen $\left(18.66 \mathrm{Jg}^{-}\right.$ $1,1.13)$, respectively. A higher enthalpy transition is needed to uncoil the long chain of amylopectin possessed by those starches. The present study showed a broad range of temperature $\operatorname{Tr}\left(33.00-39.57^{\circ} \mathrm{C}\right)$, which were comparable with the previous study of commercial starches such as corn $\left(32.2^{\circ} \mathrm{C}\right)$, sweet potato $\left(38.94^{\circ} \mathrm{C}\right)$, and potato $\left(39.87^{\circ} \mathrm{C}\right)$
[60-62]. In addition, Wani et al. [63] also reported a higher endothermic curve in $S$. sagittifolia corm starch for $T p$ $\left(101.5^{\circ} \mathrm{C}\right)$ and $T c(116.30)$ values. According to $\mathrm{Yu}$ and Christie [64], broadening or overlapping between two neighbouring peaks may be due to sampling mass higher than $5 \mathrm{mg}$ as it lowered the resolution. Higher temperatures may also cause by decreasing water/starch ratio [65].

3.6. Rheological Behaviour. Rheology is the study of the deformation and flow of food properties. According to Nurul et al. [66], starch expressed unique viscosity behaviour depending on the changes in temperature, concentration, and shear rate. Present studies showed that the viscosity decreased as the shear stress decreased as characterized by non-Newtonian fluids. Colocasia esculenta corm (46.2 mPa s) and $N$. nucifera rhizome starch $(40.9 \mathrm{mPa}$ s) possess higher viscosity in the first cycle with the shear stress of $71.71(\mathrm{~Pa})$ and $63.35(\mathrm{~Pa})$, respectively (Table 6). Both possess a waxy structure characterized by amylopectin, which yielded larger molecules than amylose [20]. On the other hand, lower viscosity was observed in the $T$. angustifolia pollen $(3.2,3.0$, and $2.9 \mathrm{mPas}$ ) due to low-amylose content, as it inhibits the swelling of granules, thus lowering the viscosity [67]. Also, T. bispinosa seed possesses the lowest viscosity and shear stress $(8.8 \mathrm{mPa}$ s/13.72 $\mathrm{Pa})$ despite having high amylopectin content. According to Singh et al. [58], higher phosphate monoesters in water caltrop may associate with amylopectin hence increase the starch viscosity while phospholipids caused opaque and decrease the viscosity pastes. The author also mentioned that starch's protein content is contradictory with peak viscosity and correlated with pasting temperature. Thus, the high phosphorus and protein content of $T$. bispinosa seed starch contribute to its low viscosity.

\section{Conclusions}

Starches from T. angustifolia (cattails) and S. sagittifolia (arrowheads) have comparable potentials to commercial aquatic macrophyte starches from $N$. nucifera (lotus), E. dulcis (Chinese water chestnut), T. bispinosa (water caltrop), and C. esculenta (taro) in food formulation. Although the least starch was isolated from T. angustifolia pollen, its higher amylose content $(36.47 \%)$ provides excellent human 
digestive tract benefits. Higher RS content was in tuber parts, i.e., rhizome and corm, than in the seed and pollen of freshwater macrophytes. Lower RS was found in N. nucifera seed starch $(27.94 \%)$ compared to others despite having higher amylose. Starch isolation procedure of T. angustifolia needs to be improvised, especially on the starch washing to prevent the impurities affecting the functional properties. Simultaneously, the procedure also must be cost-effective and efficient to be commercialized in the large-scale industry. This functionality of the native starches can later be modified and improved physically, chemically, and enzymatically which enhanced its properties and to produce novel molecules and hence can be applied in a broad range of food and nonfood applications. The starch properties in aquatic macrophytes studies showed equally good potential as the commercial starches in starch-based products.

\section{Data Availability}

The data used to support the findings of this study are included in the article.

\section{Conflicts of Interest}

The authors declare no conflicts of interest.

\section{Acknowledgments}

This research was funded and supported by an Industry Grant, Country Garden Pacific View under Seagrass Transplanting and Rehabilitation (Assisted Recovery) (6300812) and Japan Society for the Promotion of Science (JSPS), Core-to-Core Program, B. Asia-Africa Science Platforms. We would like to thank Vice-Chancellor, Universiti Putra Malaysia, for the encouragement and facilities provided. The authors would like to thank the Editor-in-Chief and two anonymous reviewers, whose constructive comments and inputs significantly improved the article.

\section{References}

[1] J. Waterschoot, S. V. Gomand, and J. A. Delcour, "Impact of swelling power and granule size on pasting of blends potato, waxy rice and maize starches," Food Hydrocolloids, vol. 52, pp. 69-77, 2016.

[2] P. Edwards, Food potential of aquatic macrophytes, International Center for Living Aquatic Resources Management, Manila, Philippines, 1980.

[3] P. Rujirapisit, "Chemical composition and some physicochemical properties of Chinese water chestnut," Starch Update, vol. 1, pp. 207-211, 2005.

[4] T. K. Lim, Edible Medicinal and Non Medicinal Plants, Springer, New York, London, 2013.

[5] R. P. Rodrigues, C. Aggarwal, and N. K. Saha, "Canning of water chestnut (Singhara) (Trapa bispinosa Roxb.)," Journal of Food Science and Technology, vol. 1, pp. 28-31, 1964.

[6] J. H. Moy and W. K. Nip, "Processed food," in A Review of Colocasia esculenta and Its Potential, J. K. Wang, Ed., University of Hawaii Press, Honolulu, 1983.
[7] Z. Q. Ling, B. J. Xie, and E. L. Yang, "Isolation, characterization, and determination of antioxidative activity of oligomeric procyanidins from the seedpod of Nelumbo nucifera Gaertn," Journal of Agricultural and Food Chemistry, vol. 53, pp. 2441-2445, 2005.

[8] S. Sukhija, S. Singh, and C. S. Riar, "Physicochemical, crystalline, morphological, pasting and thermal properties of modified lotus rhizome (Nelumbo nucifera) starch," Food Hydrocolloids, vol. 60, pp. 50-58, 2016.

[9] L. Lin, J. Huang, L. Zhao, J. Wang, and C. Wei, "Effect of granule size on the properties of lotus rhizome C-type starch," Carbohydrate Polymers, vol. 134, pp. 448-457, 2015.

[10] C. Liu, S. Wang, X. Chang, and S. W, "Structural and functional properties of starches from Chinese chestnuts," Food Hydrocolloids, vol. 43, pp. 568-576, 2015.

[11] Y. Honda, T. Mishima, H. Kaga et al., "Physicochemical properties of starch from Kaga lotus rhizome," Journal of Applied Glycoscience, vol. 61, pp. 27-29, 2014.

[12] H. Gao, J. Cai, and W. Han, "Comparison of starches isolated from three different Trapa species," Food Hydrocolloids, vol. 37, pp. 174-181, 2014.

[13] X. Lan, Y. Li, S. Xie, and Z. Wang, "Ultrastructure of underutilized tuber starches and its relation to physicochemical properties," Food Chemistry, vol. 188, pp. 632-640, 2015.

[14] A. Kurzawska, D. Górecka, W. Błaszczak, A. Szwengiel, D. Paukszta, and G. Lewandowicz, "The molecular and supermolecular structure of common cattail (Typha latifolia) starch," Starch/Starke, vol. 66, pp. 849-856, 2014.

[15] Y. Zhang, H. Zeng, Y. Wang, S. Zeng, and B. Zheng, "Structural characteristics and crystalline properties of lotus seed resistant starch and its prebiotic effects," Food Chemistry, vol. 155, pp. 311-318, 2014.

[16] T. Vasanthan, "Overview of laboratory isolation of starch from plant materials," in Current protocols in food analytical, R. E. Wrolstad, Ed., Wiley, VCH, Weinheim, 2001.

[17] AOAC International, Official Method of Analysis, Association of Official Analytical Chemists, AOAC International Publisher, Washington, DC, 19th edition, 2012.

[18] N. K. Chrungoo and A. G. Devi, "Morphological and rheological properties of starches separated from cultivars of rice (Oryza sativa L.) from North East India," American Journal of Plant Sciences, vol. 6, pp. 2019-2031, 2015.

[19] Y. Pomeranz, Functional Properties of Food Components, Academic Press, New York, 1991.

[20] S. Hegenbart, Understanding Starch Functionality, 1996, https://www.naturalproductsinsider.com/foods/ understanding-starch-functionality.

[21] J. Chattopadhyay and S. Banerjee, "Extraction of pure taro starch from local cultivars of Bengal, India and effect of seasonal variation," Annals of Sciences, vol. 2, no. 11, pp. 474483, 2013.

[22] R. F. Tester, J. Karkalas, and X. Qi, "Starch-composition, fine structure and architecture," Journal of Cereal Science, vol. 39, pp. 151-165, 2004.

[23] A. Buleon, P. Colonna, V. Planchot, and S. Ball, "Starch granules: structure and biosynthesis," International Journal of Biological Macromolecules, vol. 23, pp. 85-112, 1998.

[24] B. Svihus, A. K. Uhlen, and O. M. Harstad, "Effect of starch granule, associated components and processing on nutritive value of cereal starch: a review," Animal Feed Science and Technology, vol. 122, pp. 303-320, 2005. 
[25] S. Mishra and T. Rai, "Morphology and functional properties of corn, potato and tapioca starches," Food Hydrocolloids, vol. 20, pp. 557-566, 2006.

[26] J. O. Schmidt, S. L. Buchmann, and M. Glaum, "The nutritional value of Typha latifolia pollen for bees," Journal of Apicultural Research, vol. 28, pp. 155-165, 1989.

[27] F. E. Todd and O. Bretherick, "The composition of pollen," Journal of Economic Entomology, vol. 35, pp. 312-317, 1942.

[28] D. Stawski, "New determination method of amylose content in potato starch," Food Chemistry, vol. 110, no. 3, pp. 777-781, 2008.

[29] F. Eltaboni, A. Imragaa, K. Edbey, K. Elabdily, and N. Mousa, "Adsorption and conformations of starch at solid-liquid interfaces using spectrophotometry and turbidity techniques," American Chemical Science Journal, vol. 9, pp. 1-11, 2015.

[30] T. Cheng, X. Zheng, K. Xie et al., "Development and identification of three functional markers associated with starch content in lotus (Nelumbo nucifera)," Scientific Reports, vol. 10, pp. 17, 2020.

[31] J. Jane, L. Shen, J. Chen, S. Lim, T. Kasemsuwan, and W. Nip, "Physical and chemical studies of taro starches and flours," Cereal Chemistry, vol. 69, no. 5, pp. 528-535, 1992.

[32] K. Wuttisela, S. Shobsngob, W. Triampo, and D. Triampo, "Amylose/amylopectin simple determination in acid hydrolysed tapioca starch," Journal of the Chilean Chemical Society, vol. 53, no. 3, pp. 1565-1567, 2008.

[33] E. Sarka and V. Dvoracek, "New processing and applications of waxy starch (a review)," Journal Food of Engineering, vol. 206, pp. 77-87, 2017.

[34] Y. Zhang, X. Lu, S. Zeng et al., "Nutritional composition, physiological functions and processing of lotus (Nelumbo nucifera Gaertn.) seeds: review," Phytochemistry Reviews, vol. 14, pp. 321-334, 2015.

[35] L. Copeland, J. Blazek, H. Salman, and M. C. Tang, "Form and functionality of starch," Food Hydrocolloids, vol. 23, pp. 15271534, 2009.

[36] L. Chen, R. Liu, C. Qin et al., "Sources and intake of resistant starch in the Chinese diet," Asia Pacific Journal of Clinical Nutrition, vol. 19, no. 2, pp. 274-282, 2010.

[37] M. G. Sajilata, R. S. Singhal, and P. R. Kulkarni, "Resistant starch-a review," Comprehensive Reviews in Food Science and Food Safety, vol. 5, pp. 1-17, 2006.

[38] A. P. Nugent, "Health properties of resistant starch," British Nutrition Foundation Nutrition Bulletin, vol. 30, pp. 27-54, 2005.

[39] O. S. Kittipongpatana and N. Kittipongpatana, "Resistant starch contents of native and heat-moisture treated jackfruit seed starch," The Scientific World Journal, vol. 2015, 10 pages, 2015.

[40] S. Silvi, R. A. Cresci, and I. R. Rowland, "Resistant starch modifies gut microflora and microbial metabolism in human floraassociated rats inoculated with faeces from Italian and UK donors," Journal of Applied Microbiology, vol. 86, no. 3, pp. 521-530, 1999.

[41] C. Nishida and F. M. Nocito, "FAO/WHO scientific update on carbohydrate in human nutrition: Introduction," European Journal of Clinical Nutrition, vol. 61, no. 1, pp. 1-4, 2007.

[42] K. Baghurst, P. A. Baghurst, and S. J. Record, "Dietary fibre, non-starch polysaccharide and resistant starch intakes in Aus- tralia," in Handbook of dietary fibre in human health, G. A. Spiller, Ed., CRC Press, Boca Raton, USA, 2001.

[43] Y. N. Njintang, R. M. Nguimbou, and J. Scher, "Effect of storage on the physicochemical, functional and rheological properties of taro (Colocasia esculenta) flour and paste," Innovative Romanian Food Biotechnology, vol. 7, pp. 37-48, 2010.

[44] A. Aprinita, U. Purwandari, B. Watson, and T. Vasiljevic, "Physico-chemical properties of flours and starches from selected commercial tubers available in Australia," International Food Research Journal, vol. 16, pp. 507-520, 2009.

[45] A. Moongngarm, "Chemical compositions and resistant starch content in starchy foods," American Journal of Agricultural and Biological Sciences, vol. 8, no. 2, pp. 107-113, 2013.

[46] J. Cai, C. Cai, J. Man, W. Zhou, and C. Wei, "Structural and functional properties of C-type starches," Carbohydrate Polymers, vol. 101, pp. 289-300, 2014.

[47] S. K. Kim, J. H. Shin, S. Y. Kim, H. Y. Kim, and S. Y. Park, "Physicochemical properties of starch in water chestnut (Eleocharis kuroguwai Ohwi)," Korean Journal of Weed Science, vol. 32, no. 3, pp. 204-210, 2012.

[48] J. Man, J. Cai, C. Cai, B. Xu, H. Huai, and C. Wei, “Comparison of physicochemical properties of starches from seed and rhizome of lotus," Carbohydrate Polymers, vol. 88, pp. 676-683, 2012.

[49] A. Suzuki, M. Kaneyama, K. Shibanuma, Y. Takeda, J. Abe, and S. Hizukuri, "Physicochemical properties of Japanese arrowhead (Sagittaria trifolia L. var. sinensis Makino) starch," Denpun Kagaaku, vol. 40, pp. 41-48, 1993.

[50] W. Lan, Y. Zhihua, Z. Yun, X. Bijun, and S. Zhida, "Morphological, physicochemical and textural properties of starch separated from Chinese water chestnut," Starch/Starke, vol. 60, pp. 181-191, 2008.

[51] M. Himeda, N. N. Yanou, and R. M. Nguimbou, "Physicochemical, rheological and thermal properties of taro (Colocasia esculenta) starch harvested at different maturity stages," International Journal of Biosciences, vol. 2, no. 3, pp. 14-27, 2012.

[52] C. C. R. Wang, P. Y. Chiang, P. H. Li, and C. C. Huang, "Physicochemical properties of water caltrop (Trapa taiwanensis Nakai) starch during growth period," Carbohydrate Polymers, vol. 71, pp. 310-315, 2008.

[53] P. Y. Chiang, P. H. Li, C. C. Huang, and C. R. Wang, "Changes in functional characteristics of starch during water caltrop (Trapa quadrispinosa Roxb.) growth," Food Chemistry, vol. 104, pp. 376-382, 2007.

[54] V. Tulyathan, K. Boondee, and T. Mahawanich, "Characteristics of starch from water chestnut (Trapa bispinosa Roxb.)," Journal of Food Biochemistry, vol. 29, pp. 337348, 2005.

[55] Z. Geng, C. Zongdao, and W. Yimin, "Physicochemical properties of lotus (Nelumbo nucifera Gaertn.) and kudzu (Pueraria hirsute Matsum.) starches," International Journal of Food Science and Technology, vol. 42, pp. 1449-1455, 2007.

[56] A. Suzuki, M. Kaneyama, K. Shibanuma, Y. Takeda, and J. Abe, "Characterization of lotus starch," Cereal Chemistry, vol. 69, no. 3, pp. 309-315, 1992.

[57] H. M. Lin, Y. H. Chang, J. H. Lin, J. L. Jane, M. J. Sheu, and T. J. $\mathrm{Lu}$, "Heterogeneity of lotus rhizome starch granules as revealed by $\alpha$-amylase degradation," Carbohydrate Polymer, vol. 66, pp. 528-536, 2006. 
[58] N. Singh, J. Singh, L. Kaur, N. S. Sodhi, and B. S. Gill, "Morphological, thermal and rheological properties of starches from different botanical sources," Food Chemistry, vol. 81, pp. 219-231, 2003.

[59] R. F. Tester and W. R. Morrison, "Swelling and gelatinisation of cereal starches. I. Effects of amylopectin, amylose and lipids," Cereal Chemistry, vol. 67, pp. 551-557, 1990.

[60] Q. Lin, H. Liu, P. Xu, Z. Zhang, F. Gong, and Z. Wang, "Study on the physical and chemical properties of potato powder," Chemical Engineering Transactions, vol. 59, pp. 781-786, 2017.

[61] A. S. Babu, R. Parimalavalli, K. Jagannadham, and J. S. Rao, "Chemical and structural properties of sweet potato treated with organic and inorganic acid," Journal of Food Science and Technology, vol. 52, pp. 5745-5753, 2015.

[62] Z. Qiao, J. Gu, Y. Zuo, H. Tan, and Y. Zhang, "The effect of carboxymethyl cellulose addition on the properties of starchbased wood adhesive," BioResources, vol. 9, pp. 6117-6129, 2014.

[63] I. A. Wani, A. Gani, A. Tariq, P. Sharma, F. A. Masoodi, and H. M. Wani, "Effect of roasting on physicochemical, functional and antioxidant properties of arrowhead (Sagittaria sagittifolia L.) flour," Food Chemistry, vol. 197, pp. 345352, 2016.

[64] L. Yu and G. Christie, "Measurement of starch thermal transitions using differential scanning calorimetry," Carbohydrate Polymers, vol. 46, pp. 179-184, 2001.

[65] A. G. Maaruf, Y. B. Che Man, B. A. Asbi, A. H. Junainah, and J. F. Kennedy, "Effect of water content on the gelatinization temperature of sago starch," Carbohydrate Polymers, vol. 46, pp. 331-337, 2001.

[66] I. M. Nurul, B. N. M. N. Azemi, and D. M. A. Manan, "Rheological behaviour of sago (Metroxylon sagu) starch paste," Food Chemistry, vol. 64, no. 4, pp. 501-505, 1999.

[67] M. Schirmer, A. Hochstotter, M. Jekle, E. Arendt, and T. Becker, "Physicochemical and morphological characterization of different starches variable amylose/amylopectin ratio," Food Hydrocolloids, vol. 32, pp. 52-63, 2013. 